\title{
Penerapan Computational Thinking pada Pelajaran Matematika di Madratsah Ibtidaiyah Nurul Islam Sekarbela Mataram
}

\author{
Apriani $^{1}$, Ismarmiaty ${ }^{2}$, Dyah Susilowati ${ }^{3}$, Kartarina ${ }^{4}$, Wiya Suktiningsih ${ }^{5}$ \\ apriani@universitasbumigora.ac.id ${ }^{1}$, ismarmiaty@universitasbumigora.ac.id ${ }^{2}$, \\ dyah.bumigora@gmail.com ${ }^{3}$, augustin.kartarina@gmail.com ${ }^{4}$, \\ wiya.suktiningsih@universitasbumigora.ac.id ${ }^{5}$ \\ 1,2,3,4,5 Universitas Bumigora
}

Article History:

Received: 31-12-2020

Accepted: 28-01-2021

Keywords: Bebras, Computational Thinking, Mathematics

\begin{abstract}
This service activity aims to contribute knowledge to teachers to be able to understand and implement computational thinking in the subjects they are taught. The lack of trained personnel and the lack of understanding in implementing computational thinking gives the Bebras Bureau the opportunity to contribute. This is in line with the Mendikbud's desire to implement computational thinking in the children's education curriculum as a provision for more innovative learning to answer the needs of the industrial era 4.0. Computational thinking is the process of thinking in formulating a problem and its solution so that the solution can be represented in a form that can be executed by an information-processing agent. The implementation of the service was carried out on the Mathematics subject teacher at Nurul Islam Mataram Elementary School. The implementation stages consist of planning, preparation, socialization, training and evaluation. The results of the evaluation showed that most of the teacher participants agreed to apply the results of the training to students and most participants agreed to join the follow-up programs from Bebras. It is hoped that this activity can run continuously and be supported positively by the parties involved.
\end{abstract}

\section{Pendahuluan}

Matematika merupakan salah satu pelajaran dasar yang diberikan secara formal kepada siswa sejak Sekolah Dasar (SD)/Madratsah Ibtidaiyah(MI). Matematika dianggap sebagai salah satu mata pelajaran penting yang menjadi indikator tingkat kemampuan siswa dalam menyelesaikan pembelajaran kemampuan berpikir logis. Secara konsep, pengajaran mata pelajaran matematika diajarkan secara terstruktur mengikuti tahapan pengembangan kognisi siswa di sekolah. Penelitian Ayub et al., (2017) dalam penelitian Wijanto et al., (2019) merujuk pada hasil survey yang diterbitkan oleh Programme for International Students Assessment (PISA) menyatakan kemampuan matematika pada tahun 2012 Indonesia mencapai skor 375 dari data PISA, (2012), sempat naik pada tahun 2015 pada skor 386 PISA, (2015) lalu kembali turun pada tahun 2018 di angka 379. Nilai tersebut masih jauh dibawah dari rata-rata dengan melakukan perbandingan hasil evaluasi negara 
China dan Sigapura yang menempati peringkat tertinggi untuk skor matematika yaitu skor 591 untuk negara China dan skor 569 untuk negara Singapura OECD, (2018). Untuk meningkatkan hal tersebut, lembaga pendidikan Indonesia khususnya Kementrian Pendidikan dan Kebudayaan untuk diharapkan untuk dapat melakukan inovasi pembelajaran untuk meningkatkan literasi matematika pada pendidikan anak.

Menurut Muliawan dalam Astuti \& Leonard ( 2012) menjelaskan bahwa matematika yang dipelajari disekolah termasuk ilmu pengetahuan murni yang mengandalkan angkaangka, simbol, dan lambang. Kebutuhan keilmuan pada bidang Matematika pada tren teknologi ini berkembang pada kebutuhan inovasi pembelajaran matematika. Pada tanggal 19 Februari 2020, Kementrian Pendidikan dan Kebudayaan (Kemendikbud) mencanangkan dua kompetensi baru dalam sistem pembelajaran anak Indonesia. Dua kompetensi itu, disampaikan langsung oleh Kepala Pusat Kurikulum dan Pembelajaran Kementrian Pendidikan dan Kebudayaan adalah kompetensi computational thinking (berpikir komputasi) dan compassion CNBC Indonesia, (2020) dan Wing et al., (2007) dalam dalam tulisannya (2006) yang dimuat pada majalah Associacion of Computer and Machinery (ACM) menjelaskan bahwa berpikir komputasi adalah keterampilan fundamental bagi semua orang, tidak hanya untuk ilmuwan komputer. Selanjutnya, Wing et al., (2007) juga menyatakan bahwa untuk membaca, menulis, dan berhitung, kita harus menambahkan pemikiran komputasi ke kemampuan analitis setiap anak. Computational thingking dapat diimplementasikan pada berbagai mata pelajaran termasuk pada mata pelajaran.

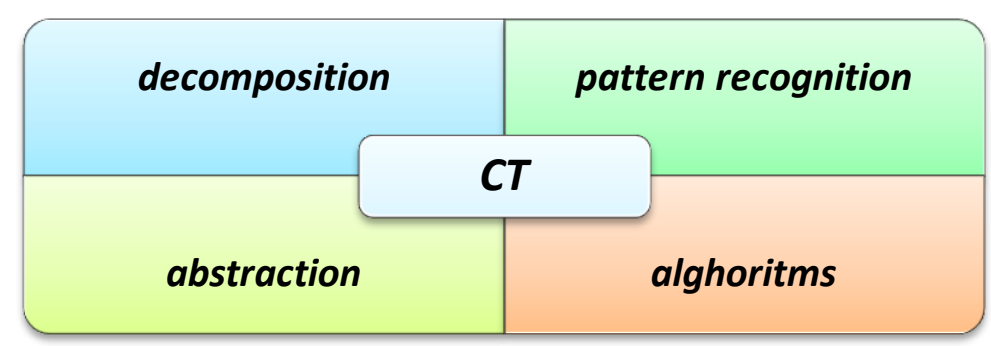

Gambar 1. Empat Key Techniques dalam Computational Thinking mengacu pada (Inggriani Liem, 2018)

Wing dalam Marieska et al., (2019) menjelaskan bahwa computational thinking adalah proses berpikir dalam merumuskan masalah dan solusinya agar solusi tersebut dapat direpresentasikan dalam bentuk yang mampu dieksekusi oleh information-processing agent. Istilah Computational Thinking (CT) pertama kali diperkenalkan oleh Seymour Papert pada tahun 1980 dan 1996. Surahman et al., (2020) dalam penelitian Marieska et al., (2019) menjelaskan bahwa Computational Thinking terdiri atas 4 key techniques yang dapat dilihat pada gambar 1, yaitu: (a) decomposition (dekomposisi) yaitu memecahkan permasalahan yang rumit menjadi bagian-bagian kecil yang lebih sederhana dan mudah dikerjakan; (b) 
pattern recognition (pengenalan pola) yaitu mencari kemiripan antara berbagai permasalahan yang disajikan untuk diselesaikan; (c) abstraction (abstraksi) yaitu berfokus pada informasi yang penting saja dan mengabaikan informasi yang dianggap tidak relevan dan (d) algorithms (algoritma) yaitu bagian yang merancang langkah-langkah untuk menyelesaikan permasalahan.

Menurut Bebras Indonesia (2017) Bebras adalah sebuah inisiatif internasional yang tujuannya adalah untuk mempromosikan Computational Thinking (Berpikir dengan landasan Komputasi atau Informatika), di kalangan guru dan murid mulai tingkat SD/MI, serta untuk masyarakat luas.Bebras Indonesia sebagai pelaksana adalah himpunan relawan dosen Perguruan Tinggi di berbagai kota di Indonesia yang turut serta dalam sebuah inisiatif internasional yang bertujuan untuk mempromosikan CT (berpikir dengan landasan komputasi atau informatika), di kalangan guru dan murid mulai tingkat SD/MI, SMP/MTs, SMA/Aliyah, serta masyarakat luas (Merdeka Belajar Melalui Computational Thinking da Gerakan PANDAI, 2020). Biro Bebras yang melaksanakan kegiatan pada pengabdian kemasyarakatan ini adalah Biro Bebras Universitas Bumigora. Beberapa kegiatan yang dilaksanakan oleh Biro Bebras Universitas Bumigora adalah Tantangan Bebras pada 3 (tiga) tingkatan SD/MI (Siaga), SMP/MTs (Penggalang) dan SMA/Aliyah (Penegak). Pada tahun ini Bebras Indonesia diberikan kesempatan untuk bekerjasama dengan Google Indonesia untuk melaksanakan kegiatan Gerakan PANDAI merupakan program yang diselenggarakan oleh Bebras Indonesia dengan disponsori oleh Google.org dan mendapat dukungan dari Direktorat Jenderal Guru dan Tenaga Kependidikan \& Direktorat Jenderal Pendidikan Tinggi Kementerian Pendidikan dan Kebudayaan. Tujuan dari gerakan ini adalah memberikan pelatihan Computational Thinking (CT) kepada guru, dengan harapan agar keterampilan yang didapatkan tersebut dapat meningkatkan keterampilan berfikir secara kritis dan kreatif para siswa serta memberikan fondasi untuk menyiapkan generasi penerus yang berdaya saing di era Revolusi Industri 4 saat ini (Merdeka Belajar Melalui Computational Thinking da Gerakan PANDAI, 2020).

Kegiatan pengabdian ini bertujuan memberikan sumbangsih pengetahuan kepada guru-guru untuk dapat memahami dan mengimplementasikan computational thinking paa mata pelajaran yang diampu. Kurangnya tenaga terlatih dan masih belum meluasnya pemahaman dalam mengimplementasikan computational thinking memberikan kesempatan kepada Biro Bebras untuk dapat berkontribusi. Hal ini selaras dengan keinginan Mendikbud untuk mengimplementasikan computational thinking pada kurikulum pendidikan anak sebagai bekal pembelajaran yang lebih inovatif untuk menjawab kebutuhan pada era industri 4.0 . 


\section{Metode}

Pelaksanaan kegiatan pengabdian ini terdiri dari dua kegiatan utama yaitu kegiatan sosialisasi Computational Thinking dan kegiatan pelatihan Computational Thinking kepada guru-guru peserta. Metode pelaksanaan yang dilakukan terdiri dari beberapa tahap antara lain: (a) Perencanaan, (b) Persiapan dan (c) Sosialisasi, (d) Pelatihan dan (e) Sosialisasi. Urutan pelaksanaan tahapan tersebut dapat dilihat pada gambar 2 .

\section{Perencan} aan
Persiapan
Sosialisasi
Pelatihan
Evaluasi

Gambar 2. Tahapan pelaksanaan gerakan pandai bebras mata pelajaran matematika di sekolah Nurul Islam

Tahapan perencanaan merupakan tahapan pertama yang dilaksanakan dalam rangkaian kegiatan pengabdian. Kegiatan ini melingkupi tahapan penentuan sasaran lingkup dan lokasi pendidikan yang akan diberikan sosialisasi dan pelatihan. Tahapan pertama diakhiri dengan hasil menentukan lokasi sekolah serta draft undangan sosialisasi. Tahapan kedua, tahapan persiapan merupakan pelaksanaan penjadwalan serta perizinan terkait dengan pelaksanaan acara sosialisasi dan pelatihan yang akan diselenggarakan pada sekolah-sekolah yang telah ditentukan. Penjadwalan kunjungan juga terkait dengan penjadwalan kegiatan sosialisasi dan pelatihan Gerakan Pandai di MI Nurul Islam seperti yang terlihat pada tabel 1.

Tabel 1. Rundown acara kegiatan sosialisasi dan pelatihan Google Pandai Bebras

Sabtu, 18 September 2020

\begin{tabular}{|c|c|c|}
\hline Pukul & Agenda & Pelaksana \\
\hline $09.00-09.30$ WITA & Rapat persiapan & $\begin{array}{l}\text { Biro Bebras } \\
\text { UBG }\end{array}$ \\
\hline $09.30-10.30$ WITA & $\begin{array}{l}\text { Pembahasan rundown acara sosialisasi dan } \\
\text { pelatihan }\end{array}$ & $\begin{array}{l}\text { Biro Bebras } \\
\text { UBG }\end{array}$ \\
\hline $10.30-11.30$ WITA & $\begin{array}{l}\text { Pembahasan materi terkait dengan mata } \\
\text { pelajaran matematika di Biro Bebras } \\
\text { Universitas Bumigora }\end{array}$ & $\begin{array}{l}\text { Biro Bebras } \\
\text { UBG }\end{array}$ \\
\hline $11.30-12.30$ WITA & Pematangan rencana kegiatan & $\begin{array}{l}\text { Biro Bebras } \\
\text { UBG }\end{array}$ \\
\hline
\end{tabular}

Selasa, 22 September 2020

\begin{tabular}{cll}
\hline \multicolumn{1}{c}{ Pukul } & \multicolumn{1}{c}{ Agenda } & \multicolumn{1}{c}{ Pelaksana } \\
\hline $09.00-09.30$ WITA & Registrasi peserta & Panitia \\
\hline $09.30-11.00$ WITA & Sosialiasi : Pengenalan Biro Bebras UBG dan & Biro Bebras \\
& Bebras Indonesia (Gerakan Pandai Google) & UBG \\
\hline $11.00-12.30$ WITA & $\begin{array}{l}\text { Sosialisasi : Pengenalan Computational } \\
\text { Thinking dalam Mata Pelajaran Matematika } \\
\text { pada Tingkat SD/MI }\end{array}$ & $\begin{array}{l}\text { Biro Bebras } \\
\text { UBG }\end{array}$ \\
& & \\
\hline
\end{tabular}


Rabu, 23 September 2020

\begin{tabular}{cll}
\hline \multicolumn{1}{c}{ Pukul } & \multicolumn{1}{c}{ Agenda } & \multicolumn{1}{c}{ Pelaksana } \\
\hline $09.00-09.30$ WITA & Registrasi Peserta & Panitia \\
\hline $09.30-11.30$ WITA & Pelatihan Computational Thinking pada Mata & Biro Bebras \\
& Pelajaran Matematika di MI Nurul Islam & UBG \\
\hline $11.30-12.00$ WITA & Evaluasi & Biro Bebras \\
& & UBG \\
\hline $12.00-12.30$ WITA & Penutupan & Pihak Sekolah \\
\hline
\end{tabular}

Tahapan selanjutnya adalah tahapan sosialisasi disampaikan materi perkenalan terkait dengan Bebras, Google Gerakan Pandai dan terkait Computational Thinking. Dilanjutkan pada tahapan pelatihan yaitu biro bebras Universitas Bumigora melaksanakan pelatihan terhadap guru-guru yang telah setuju untuk melaksanakan pengabdian. Salah satu bentuk kegiatan pelatihan adalah pendaftaran akun bebras untuk ikut serta dalam kegiatan Bebras di alamat situs http://olympia.id. tahapan terakhir yaitu tahapan evaluasi dilaksanakan untuk mengukur keberhasilan kegiatan dengan target pencapaian dan harapan Biro Bebras dalam mengimplementasikan computational thinking pada sekolah yang dituju.

\section{Pembahasan}

Pelaksanaan kegiatan sosialisasi dan pelatihan telah sukses dilaksanakan pada hari Rabu, tanggal 23 September 2020 di MI Nurul Islam Sekarbela Mataram. Beberapa hasil kegiatan sesuai dengan tahapan pelaksanaan dijelaskan sebagai berikut:

\section{a. Tahapan Perencanaan}

Tahapan perencanaan dilakukan setelah mendapatkan berita terkait dengan adanya kegiatan Gerakan Pandai, Biro Bebras Universitas Bumigora yang dikepalai oleh Kartarina Agustin, M.Kom. bersama relawan biro melaksanakan rapat terkait kegiatan Gerakan Pandai dengan hasil draft persiapan kegiatan sosialisasi dan pelatihan Computational Thinking di sekolah-sekolah pada area Lombok termasuk kota Mataram. Salah satu sekolah yang dituju untuk dilaksanakannya sosialisasi adalah Madrasah Ibtidaiyah Nurul Islam di kota Mataram.

\section{b. Tahapan Persiapan}

Tahapan ini dilaksanakan dengan pengurusan perizinan dan persiapan materi terkait dengan pelatihan. Materi Computational Thinking yang akan diimplementasikan ke dalam mata pelajaran matematika didiskusikan terlebih dahulu oleh tim biro Bebras Universitas Bumigora sebagai persiapan pelatihan. Kegiatan persiapan dapat ditunjukkan pada gambar 3. 


\section{ADMA}

Qurnal Pengabdian dan Pemberdayaan Masyarakat
2021, VoL 1, No.2, Hal. 47-56

Doi: 10.30812/adma.v1i2.1017

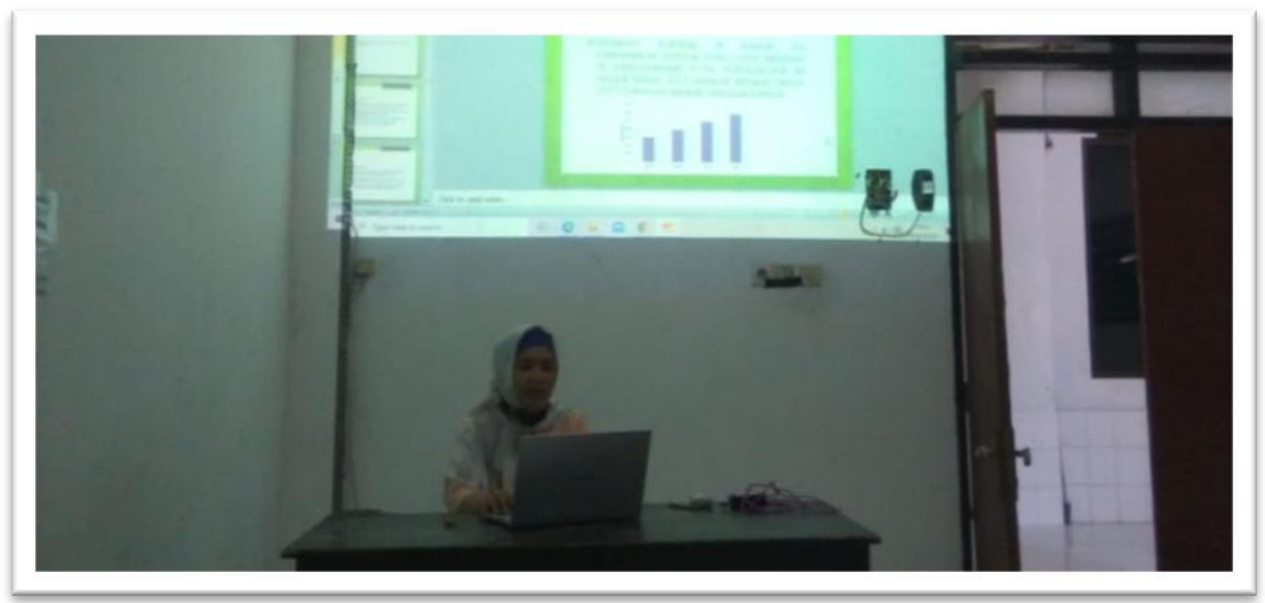

Gambar 3. Kegiatan diskusi materi pelatihan pada persiapan sosialisasi dan pelatihan

Gerakan Pandai Bebras

\section{c. Tahapan Sosialisasi}

Tahapan sosialisasi dilaksanakan dengan menyampaikan terkait dengan Computational Thinking, pengenalan Biro Bebras Universitas Bumigora sebagai Pelaksana kegiatan nasional Bebras Indonesia. Tujuan dan manfat kegiatan Bebras dijelaskan pada kegiatan ini kepada pihak MI Nurul Islam Mataram.

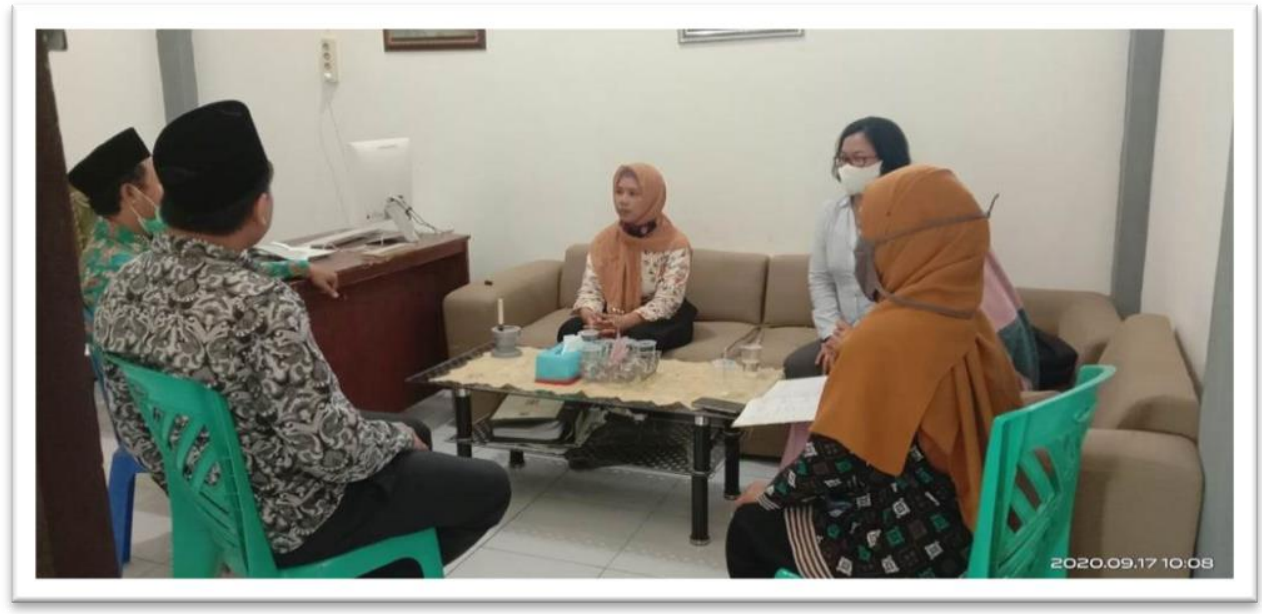

Gambar 4. Pelaksanaan sosialisasi terkait kegiatan Gerakan Pandai Bebras Indonesia di Madrasah Ibtidaiyah Nurul Islam

\section{d. Tahapan Pelatihan}

Tahapan terakhir, yaitu pelatihan terkait materi Computational Thinking pada guru-guru sekolah MI Nurul Islam. Pelaksanaan kegiatan dilaksanakan di ruang pertemuan sekolah dengan dihadiri guru-guru yang berkesesuaian dengan mata pelajaran matematika di MI Nurul Islam. Gambar kegiatan pelatihan dapat dilihat pada gambar 5, sedangkan tampilan materi yang disampaikan pada gambar 6 . 


\section{ADMA}

Qurnal Pengabdian dan Pemberdayaan Masyarakat
2021, VoL 1, No.2, Hal. 47-56

Doi: 10.30812/adma.v1i2.1017

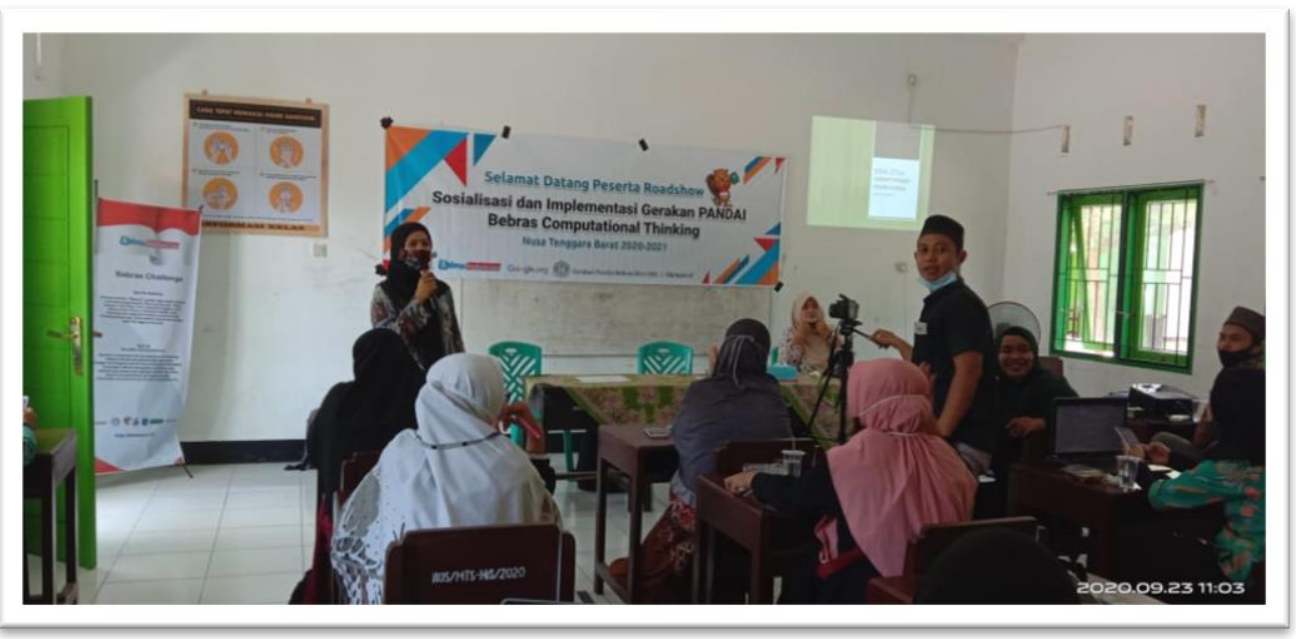

Gambar 5. Pelaksanaan pelatihan terkait kegiatan Gerakan Pandai Bebras Indonesia di MI Nurul Islam

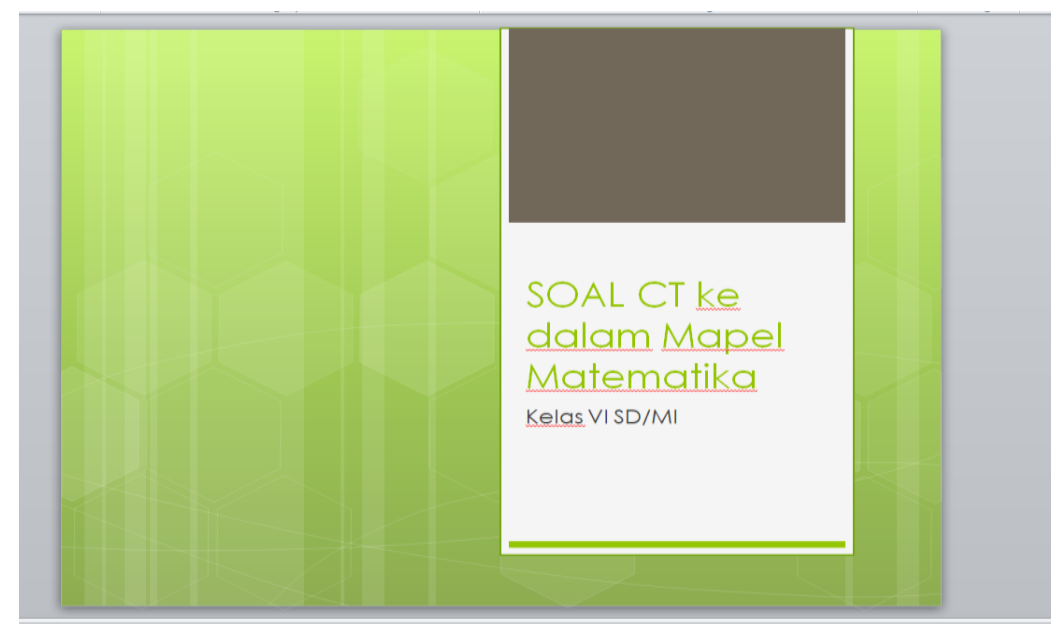

Gambar 6. Tampilan awal materi Computational Thinking pada mata pelajaran Matematika yang akan disampaikan

\section{e. Tahapan Evaluasi}

Kegiatan dilaksanakan selama 3 (tiga) hari dengan susunan kegiatan mengikuti protokol kesehatan yang sesuai selama masa pandemi berlangsung. Kegiatan sosialisasi dan pelatihan dilaksanakan secara tertib dan khidmat. Hasil evaluasi dilaksanakan dengan menggunakan kuesioner sebagai pengukur kepuasan pelaksanaan kegiatan dan sebagai evaluasi pelaksanaan kegiatan yang dilakukan. 


\section{ADMA}

Gurnal Pengabdian dan Pemberdayaan Masyarakat
2021, VoL 1, No.2, Hal. 47-56

Doi: 10.30812/adma.v1i2.1017

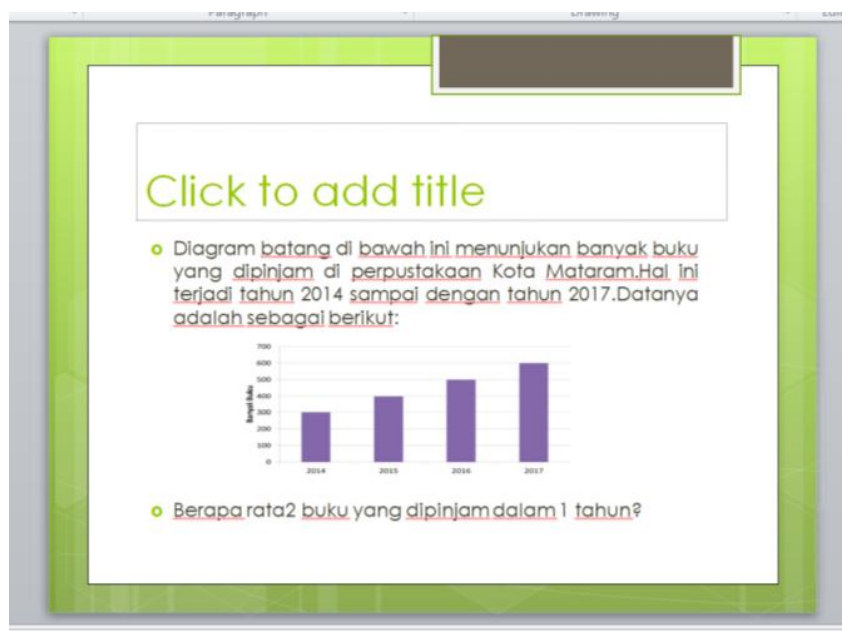

Gambar 7. Tampilan contoh soal Computational Thinking pada mata pelajaran Matematika

Hasil pengabdian masyarakat yang telah dilaksanakan, didiskusikan di bagian ini dalam dua bagian. Bagian pertama, terkait dengan analisa materi pelaksanaan pelatihan. Gambar 7 memperlihatkan contoh soal matematika yang dianggap telah menyesuaikan dengan materi Computational Thinking yang dibutuhkan. Analisa yang dilaksanakan sebagai bentuk monitoring isian pelatihan yang telah sesuai dengan prosedur pelatihan materi implementasi Computational Thinking. Soal yang digunakan dalam implementasi haruslah soal yang telah memenuhi kebutuhan dekomposisi, abstraksi, pengenalan pola dan algoritma untuk memberikan pemahaman kepada guru terkait Computational Thinking dalam soal mata pelajaran Matematika di MI Nurul Islam. Hasil analisa soal dapat dilihat pada tabel 2 dibawah ini.

Tabel 2. Hasil analisis Computational Thinking pada soal Matematika

\begin{tabular}{|c|c|c|}
\hline No. & Key Technique & Analisis \\
\hline 1. & Decomposition & $\begin{array}{l}\text { Menentukan jumlah lompatan kekiri dan jumlah lompatan ke } \\
\text { kanan }\end{array}$ \\
\hline 2. & $\begin{array}{l}\text { Pattern } \\
\text { Recognize }\end{array}$ & $\begin{array}{l}\text { Mengenali pola gerakan tupai.Tupai melompat ke arah kiri (ke } \\
\text { arah kiri titik } 0 \text { artinya daerah bilangan negatif) dan tupai } \\
\text { melompat ke kanan (positif). }\end{array}$ \\
\hline 3. & Abstraction & Menentukan posisi terakhir tupai, mengetahui jumlah lompatan \\
\hline 4. & Algorithm & $\begin{array}{l}\text { Menentukan jumlah lompatan sampai titik terakhir: } \\
\text { (a) Jumlah lompatan tupai yaitu sebanyak } 2 \text { kali ke kanan }(2 \\
\times 3=6 \text { ) } \\
\text { (b) Tupai melompat sebnyak } 3 \text { kali ke kiri }\left(-3^{\star} 3=-9\right) \\
\text { (c) Posisi tupai }=6+(-9)=-3 \\
\text { Jadi posisi tupai adalah di }-3\end{array}$ \\
\hline
\end{tabular}

Bagian kedua, terkait dengan diskusi hasil kegiatan adalah terkait dengan hasil kuesioner yang telah dilakukan. Hasil kuesioner menunjukkan $86 \%$ guru menyatakan bahwa Computational Thinking perlu diajarkan kepada siswa sedangkan sisanya (10\%) menyatakan sangat setuju, selain daripada itu $76 \%$ guru menyatakan setuju untuk https://journal.universitasbumigora.ac.id/index.php/ADMA 
melaksanakan program lanjutan secara berkesinambungan terkait dengan pelatihan implementasi Computational Thinking pada mata pelajaran Matematika yang diampu oleh guru tersebut.

\section{Kesimpulan}

Kegiatan pengabdian terkait dengan Computational Thinking telah dilaksanakan. Hasil pelaksanaan telah dievaluasi dengan hasil bahwa sebagian besar peserta guru setuju untuk menerapkan hasil pelatihan terkait Computational Thinking kepada siswa dan juga sebagian besar peserta menyatakan setuju untuk bergabung pad program-program lanjutan dari Bebras. Diharapkan kegiatan ini dapat berjalan secara berkesinambungan dan didukung secara positif oleh pihak-pihak yang terlibat.

\section{Ucapan Terimakasih}

Terimakasih diucapkan kepada Biro Beras Indonesia khususnya pada Biro Bebras Universitas Bumigora yang telah memberikan kesempatan yang begitu berharga untuk dapat berkontribusi dalam kegiatan Gerakan Pandai. Selain itu ucapan terimakasih diberikan kepada Universitas Bumigora selaku tempat bernaung Biro Bebras Universitas Bumigora. Ucapan terimakasih juga diberikan kepada Dinas Pendidikan dan Kebudayaan Kota Mataram yang telah membantu dalam hal koordinasi data dan perijinan terkait terlaksananya kegiatan ini dan ucapan terimakasih yang besar kepada pihak MI Nurul Islam Mataram yang telah bersedia bekerjasama dalam melaksanakan kegiatan ini.

\section{Daftar Pustaka}

Astuti, A., \& Leonard. (2012). Peran Kemampuan Komunikasi Matematika Terhadap Prestasi Belajar Matematika Siswa. Jurnal Formatif, 2(2), 102-110. https://doi.org/10.1016/0749-6036(91)900878

Ayub, M., Wijanto, M. C., Senjaya, W. F., Karnalim, O., Kandaga, T., Witono, T., Edi, D., Sujadi, S. F., Kartawihardja, D. S., Santosa, S., \& Gantini, T. (2017). Edukasi Berpikir Komputasional Melalui Pelatihan Guru dan Tantangan Bebras untuk Siswa di Bandung pada Tahun 2016. Prosiding Seminar Nasional Pengabdian Kepada Masyarakat 2017 Vol. 2 No. 2 ISSN. 2541-3805, 2(2), 12-18. https://doi.org/10.31227/osf.io/gwfv5

Bebras Indonesia. (2017). Apa Itu Bebras. Bebras Indonesia. http://bebras.or.id/

CNBCIndonesia. (2020). Nadiem Usung Computational Thinking Jadi Kurikulum, Apa itu? CNBC Indonesia. http://cnbcindonesia.com

Inggriani Liem. (2018). Computational Thinking \& Bebras Indonesia. In Software Architecture Conference 2018. http://www.mpjasin.gov.my/ms/jasin/profil/latar-belakang

Marieska, M. D., Rini, D. P., Oktadini, N. R., Yusliani, N., \& Yunita. (2019). Sosialisasi dan Pelatihan Computational Thinking untuk Guru TK, SD, dan SMP di Sekolah Alam Indonesia (SAI) Palembang. Prosiding Annual Research Seminar 2019: Computer Science and ICT, 5(2), 7-10.

Merdeka Belajar Melalui Computational Thinking da Gerakan PANDAI. (2020). Universitas Sanata Dharma.

OECD. (2018). What 15-year-old students in Indonesia know and can do. Programme for International Student Assessment (PISA) Result from PISA 2018, 1-10. http://www.oecd.org/pisa/ Data 
OECD, PISA 2012 Result in Focus: What 15-year-olds know and whatthey can do with what they know, (Paris, France: OECD, 2014)

OECD. (2016). PISA 2015 Results (Volume I): Excellence and Equity in Education. In PISA.https://doi.org/10.1787/9789264266490-en

Surahman, E., Ulfa, S., Sulthoni, \& Sumaji. (2020). Pelatihan Perancangan Pembelajaran Thinking untuk Guru Sekolah Dasar Berbasis Computational Pendahuluan. JURPIKAT ( Jurnal Pengabdian Kepada Masyarakat ), 1(2), 60-74.

Wijanto, M. C., Ayub, M., Senjaya, W. F., Toba, H., Santosa, S., Karnalim, O., Kandaga, T., Panca, B. S., Sujadi, F. S., Edi, D., \& Adelia. (2019). Evaluasi Pelaksanaan Tantangan Bebras untuk Siswa di Biro Universitas Kristen Maranatha pada tahun 2017 - 2018 untuk Edukasi Computational Thinking. Prosiding Seminar Nasional Hasil Pengabdian Kepada Masyarakat, 4(1), 295-301.

Wing, J. M., Henderson, P. B., Cortina, T. J., \& Hazzan, O. (2007). Computational Thinking. SIGCSE'07, 49(3). https://doi.org/https://doi.org/10.1145/1118178.1118215 